Final Report on 2008 MIT Clean Energy Entrepreneurship Prize Competition V6 Page 1

\title{
Massachusetts Institute of Technology Clean Energy Entrepreneurship Prize 2008 Final Report DOE Award \# DE- FG36-07G017110
}

Project Director: William Aulet

\author{
Principal Investigator: Charlie Cooney
}

\section{Summary}

The MIT Clean Energy Prize was established to accelerate the pace of innovation in the energy space, specifically with regard to clean energy and to reduce our dependence on foreign oil. Through a prize structure designed to incent new ideas to be brought forward coupled with a supporting infrastructure to educate, mentor, network and provide a platform for visibility, it was believed we could achieve this goal in a very efficient and effective manner. The grand prize of $\$ 200 \mathrm{~K}$ was meant to be the highly visible and attractive carrot to achieve this and through a public-private partnership of sponsors who held a long term view (i.e., they were not Venture Capitalists or law firms looking for short term business through advantaged deal flow). It was also designed to achieve this in a highly inclusive manner. Towards this end, while MIT was the platform on which the competition was run, and this brought some instant cache and differentiation, the competition was open to all teams which had at least one US citizen. Both professional teams and student teams were eligible. Looking back it is clear the competition was a huge success. We achieved our goal with very little lead time (the competition was announce essentially on December 1,2007 with submissions due in at the end of February). We had 91 legitimate entries from a wide variety of disciplines in clean energy and this involved approximately 400 people. The final 20 candidates were all very strong and we estimate that half of them will get funded. Of the final five candidates, the winner has since been funded by Kleiner Perkins Caufield \& Byers for a reported $\$ 10$ million after it chose them from over a dozen pursuing VC firms. The winner, FloDesign Wind Turbine Corporation, of Wilbraham, Massachusetts, directly attributes its success to the competition giving them valuable support and enhanced visibility. The runner up, Covalent Solar, has since had over 100 articles in leading publications like the Economist, the Financial Times, the Wall Street Journal, Boston Globe and Science about the company and it has multiple offers of funding in front of them. With the remaining three of the five finalists, the competition has helped them become connected to large companies or funding sources with whom they are now in active discussions with to obtain significant financial support. This investment will be instrumental in turning their ideas into real and sizeable ventures that have the opportunity to impact very positively our energy landscape. We know the competition helped them develop their business plans and gain the network and visibility to achieve this success.

Probably even more importantly, the competition has inspired scores of additional people to think about new ideas and provides a platform (an "American Idol" if you will) for energy entrepreneurs to bring their ideas forward in the future and to develop them, get support and get recognized. The anticipation for the MIT Clean Energy Prize 2009 is palpable and we expect to be an even greater success. All of this would not have been possible without the generous financial and other support (personnel with expertise) provided by the US DOE, NSTAR and the Kauffman Foundation in line with the long term vision. In addition to the teams, it should be noted that the volunteers worked tirelessly which is what gave such tremendous leverage to the monies donated so we could achieve this goal with such relatively small amount of overall investment. It was truly a great ROI for the American public.

\section{Managing Team and Oversight}

The prize was overseen by William (Bill) Aulet (Chairman of the MIT Clean Energy Prize as well as Senior Lecturer at MIT Sloan School and Entrepreneur in Residence at the MIT Entrepreneurship Center) who Final Report on 2008 MIT Clean Energy Entrepreneurship Prize Competition V6 Page 2 
helped design a governance structure, helped the organizing team to formulate the original processes to be effective and independent and was involved as necessary in this first year to insure the competition was a success. On the steering committee with Bill was Professor Charles Cooney (MIT Professor of Chemical Engineering and Chairman of the Deshpande Center) and Joseph Hadzima (Chairman of the MIT Enterprise Forum). The other key oversight function was performed by Tod Hynes (Director of Alternative Energy for Citizens Energy) as he chaired the Executive Judging Committee which oversaw the integrity of the judging process ranging from selection of the judges, to handling of potential conflict of interests to managing the process itself through the competition.

From an operations standpoint, MIT students ran the daily operations led my Elizabeth Willett (Managing Director) who oversaw all the operations. She had a lead for judging (Jean Ng who also worked very closely with Tod Hynes), programs (Chad Lovell) and sponsorship (Phil Stephenson). All of these people were volunteers as were all the people who worked on the competition and no one received any compensation. Considering it was the first year, there was not much time and there was no precedent or existing infrastructure, they did an incredible job.

\title{
Competition Process
}

Networking \& Team Building (from September 18th to Feb 28th): Student teams developed and sharpened their entrepreneurship skills. Some student teams participated in an elevator pitch competition, executive summary contest, entrepreneurship seminars, Energy Week and other activities part of the MIT 100K platform, which were leveraged through pod casts, FaceBook and LinkedIn.

Entries Dues (February 28th): 91 teams submitted a 1,000 word business plan executive summary and small 10 page power point presentation.

Qualification Round (February 29th - March 2nd): The Prize Executive Judging Committee selected 40 teams that advanced to the next round.

Semi Finals (March 6th): Judging panel selected 20 teams as semi finalist participants. Teams were assigned a legal mentor and a venture mentor to develop their business plan and market strategy. The semi-finalist teams had a two-month period to hone their plan and presentation with the benefit of intense mentoring, training and skills development.

Finals (May 1st - May 8th): The 20 semi-finalist teams submitted a full business plan and a slide deck, presented it and responded to questioning by a panel of judges. Five teams were selected as finalists.

Grand Prize Award and Ceremony (May 13th): After presenting in front of a distinguished panel of judges all the winning teams were recognized and announced and in a special ceremony by NSTAR Chairman, President and CEO Tom May, U.S. Department of Energy Senior Advisor of Energy Efficiency and Renewable Energy, Drew Bond and MIT Energy Initiative Director, Professor Ernie Moniz.

\section{PARTICIPATING ORGANIZATIONS}

\section{Prize Sponsors:}

\author{
U.S. Department of Energy \\ NSTAR \\ Kauffman Foundation \\ MIT 100K Organization
}

\section{Competition Sponsors:}

$\square$ Chesonis Family Foundation

Final Report on 2008 MIT Clean Energy Entrepreneurship Prize Competition V6 Page 3 
$\square$ Applied Ventures LLC, venture fund of Applied Materials

\title{
Supporting Organizations:
}

\author{
$\square$ MIT Entrepreneurship Center \\ $\square$ MIT Energy Club \\ MIT Energy Initiative \\ MIT Sloan School of Management \\ MIT School of Engineering \\ MIT Enterprise Forum
}

Judges and Mentors Grand Prize Judges (May 13th 2008)

\section{Jacques Beaudry-Losique \\ Ian Bowles

Gerd Goette
Peter Herbert
Mark Kalpin
Jim Matheson
Ken Morse
Dan Nova
Werner J. Schweiger

Finalist Judges (May 8th 2008)

Howard Anderson

Beth Cohen

Steven Connors

Philip Giudice

Christine A. Gulbranson, $\mathrm{PhD}$

William D. Lese

Aaron Mandel

Michael Pomianek

John Preston

Steve Taub

Matthew Trevithick

Ed Wall

\section{Semi-finals
Kerry Bowie}

Nolan Browne

Tom Burton

Robert M. Day

Jacquelynn Henke

Dr. Marie Mapes

John Miller

Joel Moxley
Program Manager, Office of Biomass

Secretary, Executive Office of Energy

and Environmental Affairs

Managing Partner

Co-Founder \& Managing Partner

Partner

General Partner

Managing Director

General Partner

Senior Vice President Operations

Bill Porter Professor of

Entrepreneurship

Director of Emerging Growth Services

Director of Analysis Group for

Regional Energy Alternatives

Commissioner

Director Advancing Innovations

Managing Director

Founder and Managing Partner

Shareholder

Senior Lecturer

Senior Vice President, Strategic

Marketing - Renewables

Partner

Program Manager -FreedomCAR \&

Vehicle Technologies, EERE

2008)

Special Assistant to the

Undersecretary for Environment,

Executive Office of Energy \&

Environmental Affairs

Director of Business Development

Chair of Energy and Clean Tech

Principal

Development \& Advisory Services

Group

Presidential Management Fellow

Entrepreneur-in-Residence \&

Operations Manager

Founder
U.S. Department of Energy

U.S. Department of Energy

Siemens Venture Capital

Lux Capital Management

WilmerHale

Flagship Ventures

MIT Entrepreneurship Center

Highland Capital Partners, Inc.

NStar

MIT Entrepreneurship Center

WolfBlock, LLC

MIT Energy Initiative

Division of Energy Resources,

Massachussetts Commonwealth

Kauffman Foundation

Braemer Energy Ventures

Great Point Ventures

Wolf Greenfield, LLC

MIT Entrepreneurship Center

GE Energy Financial Services

Venrock

U.S. Department of Energy

U.S. Department of Energy

EverGreen Solar

Mintz Levin

@Ventures

Colliers Meredith \& Grew

U.S. Department of Energy

ATMC, UMass - Dartmouth

Stericoat 